\title{
Complex Trait Analysis of the Hippocampus: Mapping and Biometric Analysis of Two Novel Gene Loci with Specific Effects on Hippocampal Structure in Mice
}

\author{
Lu Lu, David C. Airey, and Robert W. Williams \\ Center for Neuroscience, Department of Anatomy and Neurobiology, University of Tennessee Health Science Center, \\ Memphis, Tennessee 38163
}

\begin{abstract}
Notable differences in hippocampal structure are associated with intriguing differences in development and behavioral capabilities. We explored genetic and environmental factors that modulate hippocampal size, structure, and cell number using sets of C57BL/6J (B6) and DBA/2J (D2) mice; their F1 and F2 intercrosses $(n=180)$; and 35 lines of BXD recombinant inbred (RI) strains. Hippocampal weights of the parental strains differ by $20 \%$. Estimates of granule cell number also differ by $\sim 20 \%$. Hippocampal weights of RI strains range from 21 to $31 \mathrm{mg}$, and those of individual F2 mice range from 23 to $36 \mathrm{mg}$ (bilateral weights). Volume and granule cell number are well correlated $(r=0.7-0.8)$. Significant variation is associated with differences in age and sex. The hippocampus increases in weight by 0.24 $\mathrm{mg}$ per month, and those of males are $0.55 \mathrm{mg}$ heavier (bilateral) than those of females.
\end{abstract}

Heritability of variation is $\sim 50 \%$, and half of this genetic variation is generated by two quantitative trait loci that map to chromosome 1 (Hipp1a: genome-wide $p<0.005$, between 65 and $100 \mathrm{cM}$ ) and to chromosome 5 (Hipp5a, $p<0.05$, between 15 and $40 \mathrm{cM})$. These are among the first gene loci known to produce normal variation in forebrain structure. Hipp1a and Hipp5a individually modulate hippocampal weight by 1.0-2.0 $\mathrm{mg}$, an effect size greater than that generated by age or sex. The Hipp gene loci modulate neuron number in the dentate gyrus, collectively shifting the population up or down by as much as 200,000 cells. Candidate genes for the Hipp loci include Rxrg and Fgfr3.

Key words: dentate gyrus; granule cells; complex trait analysis; heritability; quantitative trait locus; $B X D$ recombinant inbred strain; C57BL/6; DBA/2; spatial memory
Structural variation in hippocampus can be substantial. Among normal humans hippocampal volume varies approximately twofold-from 6 to $11 \mathrm{~cm}^{3}$ (Csernansky et al., 1998; De Bellis et al., 2000). This variation is generated and maintained in large part by differences in gene sequences and gene expression levels. Classic biometric studies by Richard and Cynthia Wimer and their colleagues demonstrated that pervasive differences in hippocampal structure among inbred strains of mice are attributable to a complex mixture of genetic, environmental, and maternal effects (Wimer and Wimer, 1971; Barber et al., 1974; Wimer et al., 1976, 1978, 1982, 1983). This well characterized variation in mice is now especially intriguing for two reasons. First, the discovery, characterization, and manipulation of neuronal and glial stem cells in rodent forebrain (Altman and Das, 1965; Bayer, 1982; Kaplan and Bell, 1984; Stanfield and Trice, 1988; Cameron et al., 1993; Gould et al., 1994) has invigorated research directed at isolating factors that modulate rates of stem cell cycling and proliferation (Palmer et al., 1997; Kuhn et al., 1997; Kempermann et al., 1997ab, 1998). Gage and colleagues have shown marked differences in the dynamics of cell proliferation in the dentate

\footnotetext{
Received Dec. 18, 2000; revised Feb. 23, 2001; accepted March 7, 2001.

This research project was supported by National Institute of Neurological Disorders and Stroke Grant R01 NS35485. We thank Drs. Guomin Zhou, Jing Gu, and Xiyun Peng for their assistance in generating, processing, and genotyping F2 and BXD mice. We thank Dr. Anand Kulkarni, Toppy Malasri, and David Seecharan for their assistance in the stereological analysis of the dentate gyrus. We thank Dr. Wim Crusio for comments on a draft of this paper.

Correspondence should be addressed to Dr. Lu Lu, Center for Neuroscience, Department of Anatomy and Neurobiology, University of Tennessee Health Science Center, 855 Monroe Avenue, Memphis, TN 38163. E-mail: lulu@nb.utmem.edu and rwilliam@nb.utmem.edu.

Copyright (c) 2001 Society for Neuroscience $0270-6474 / 01 / 213503-12 \$ 15.00 / 0$
}

gyrus among inbred strains, including the two key strains, C57BL/6 and DBA/2, that we have used in the present study (Kempermann et al., 1998) (G. Kempermann, personal communication).

The second complementary reason to be interested in strain differences is that recent advances in molecular genetics and in complex trait analysis now make it practical to map, characterize, and clone gene loci that influence a wide range of heritable neuroanatomical and behavioral traits (Williams, 1998; Rikke and Johnson, 1998; Sandberg et al., 2000; Williams, 2000; Belknap et al., 2001). Complex trait analysis initially involves associating differences in alleles at defined chromosomal positions with differences in a trait-in this study with the size, architecture, and cellular composition of the mouse hippocampus. A strong association between differences in phenotypes and genotypes indicates the presence and position of a quantitative trait locus (QTL) (Darvasi, 1998; Williams, 2000). Complex trait analysis has proved to be highly effective for neuroanatomical and behavioral traits. For example, by taking advantage of differences between several strains of mice, we have recently succeeded in mapping sets of gene loci that modulate large scale traits such as total brain weight (Strom, 1999; Williams, 2000) and total cerebellar size (Airey et al., 2001) as well as more refined traits such as single neuron cell populations (Strom and Williams, 1998; Williams et al., 1998; Strom, 1999).

In this study we use biometric and genetic techniques to explore the basis of variation in the size, structure, and cell populations of the hippocampus. Our work begins with a systematic multiple linear regression analysis of the effects of age, sex, body, and brain weight on the adult hippocampus. This work is of 
interest in its own right, but in the context of gene mapping studies is a prelude to interval mapping. We have succeeded in identifying and verifying two gene loci that control the size of the hippocampus. These are among the first QTLs associated with normal variation in forebrain anatomy in any vertebrate. We have examined the cytoarchitecture of the hippocampus and granule cell density in the dentate gyrus to access the scope of action of these novel gene loci.

\section{MATERIALS AND METHODS}

Two complementary groups of mice were used in this study. The first consisted of a set of $35 \mathrm{BXD} / \mathrm{Ty}$ recombinant inbred (RI) strains. All of these strains were used both for gene mapping and for the biometric analysis of the hippocampus and its parts. The BXD RI strains were generated by crossing C57BL/6J (B6) and DBA/2J (D2) parental strains in the mid-1970s (BXD1 through 32) and 1990s (BXD33 through 42) by Taylor (1989) and Taylor et al. (1999). RI strains are completely inbred lines derived from brother-sister matings starting from an F2 intercross. They are advantageous for complex trait analysis for several reasons explained in Williams $(1998,2000)$. First, numerous individuals with identical genomes can be phenotyped, and this greatly improves the precision of phenotypes because the key parameter used during mapping is a strain average rather than an individual value. We typically averaged values from eight animals for weight data and five animals for volumetric data and cell counts (both sides were analyzed in all cases). The coefficient of error (SEM/mean) of hippocampal weight data averages only $1.8 \%$, whereas the corresponding coefficient of variation $(\mathrm{SD} /$ mean) averages $3.7 \%$ (Table 1). A related advantage of RI strains is that they can be used by many investigators over a period of many years. The large strain differences in hippocampal structure and cell density that we report in this study can now be followed up by developmental, physiological, pharmacological, and behavioral studies.

The second group of mice that we used consisted of reciprocal F1 and F2 intercrosses between B6 and D2, the same strains used to make the BXD RI strains. With the exception of any new mutations, the RI and the F2 mapping panels share precisely the same sets of parental alleles. The F2 animals were generated at the University of Tennessee by intercrossing both BDF1 and DBF1 mice, as described in Zhou and Williams (1999); 105 of the animals were BDF2s, and 75 of the animals were DBF2s. An F2 intercross is often used to complement the analysis of recombinant inbred strains, and in this study we have used the F2 to confirm and refine the location of QTLs that modulate hippocampal weight. An F2 intercross has the advantage over the RI set of a much larger number of genomes to correlate with phenotypes. The disadvantage to this cross is the effort required to genotype each individual mouse. In our study 180 animals were genotyped at 145 microsatellite marker loci as describe below.

Animal husbandry and age. Mice were maintained at $20-24^{\circ} \mathrm{C}$ on a $14 / 10 \mathrm{hr}$ light/dark cycle in a pathogen-free colony at the University of Tennessee. Most animals were fed a 5\% fat Agway Prolab 3000 rat and mouse chow and given tap water in glass bottles. The average age of $\mathrm{BXD} / \mathrm{Ty}$ animals was $80 \mathrm{~d}$; that of F2 mice was $98 \mathrm{~d}$. Parental strains and the set of BXD/Ty strains were obtained from the Jackson Laboratory (Bar Harbor, ME) from 1994 through 2000.

Fixation. Mice were deeply anesthetized with Avertin (1.25\% 2,2,2tribromoethanol and $0.8 \%$ tert-pentyl alcohol in water; $0.5-1.0 \mathrm{ml}$, i.p.). Most mice were perfused through the heart with $0.1 \mathrm{M}$ PBS followed by $1.25 \%$ glutaraldehyde and $1.0 \%$ paraformaldehyde in $0.1 \mathrm{M}$ phosphate buffer, and then by $2.5 \%$ glutaraldehyde and $2.0 \%$ paraformaldehyde in $0.1 \mathrm{M}$ buffer.

Dissection and weight of the hippocampus. Fixed brains were bisected along the midline. Left and right hippocampal regions were dissected under a dissecting microscope by inserting fine blunt forceps into the ventricular cavity just dorsal to the hippocampus and removing overlying cortex and callosum (Fig. 1). The surface of the hippocampus and dentate gyrus was used to guide removal of cortex along the septotemporal axis. The exposed hippocampus and dentate gyrus was pulled free of the hemisphere in a ventral-to-dorsal direction. The dorsoanterior aspect of each hippocampus was trimmed free of septum and dorsal fornix, rolled quickly in tissue paper, and immediately weighed to the nearest $0.1 \mathrm{mg}$. The dissection includes a small part of the subiculum adjacent to CA1 and occasionally a small strand of the fimbria. To ensure low technical error, all dissections were performed by the first author. Original data files are available at www.nervenet.org/papers/hipp2000.html.

Volumetric measurement of the hippocampus. A second independent set of 31 BXD strains and the two parental strains that are part of the Mouse Brain Library (www.mbl.org) was studied to assess the reliability of the weight data and to determine if QTLs affecting hippocampal size have regional effects limited to the dentate gyrus, the hippocampus proper, the pyramidal cell layer, or the granule cell layer. Images of the serial sections through the entire hippocampus from 154 BXD cases (average of five per strain), $8 \mathrm{C} 57 \mathrm{BL} / 6 \mathrm{~J}$ cases, and $6 \mathrm{DBA} / 2 \mathrm{~J}$ cases were downloaded from www.mbl.org and analyzed in NIH Image. Images were not available for four BXD strains $6,16,21$, and 37. Serial section images have a resolution of $4.5 \mu \mathrm{m} /$ pixel. The interval between adjacent sections on each slide is $300 \mu \mathrm{m}$. Borders of the hippocampus, excluding the subiculum, but including the fimbria and dentate gyrus (Fig. 1a-e) were traced manually. The dentate gyrus was traced separately. The area of the set of sections was multiplied by the section interval to estimate volume. Finally, areas of the pyramidal cell layer (CA1-CA3) and the granule cell layer were measured bilaterally for all cases. These layers have a high cell packing density and can be reliably defined by a thresholding operation in NIH Image. To improve uniformity of the data set, the first author conducted all thresholding. The reliability of thresholding was tested by repeated measures analysis. The correlation of duplicated estimates is 0.95. Shrinkage among cases in the Mouse Brain Library is variable, but known. To correct for variance caused by shrinkage, we divided hippocampal volumes by the total brain volume and then multiplied by the brain volume expected from the known brain weight, assuming a brain density of $\sim 1.05 \mathrm{mg} / \mathrm{mm}^{3}$ of fixed tissue. The postprocessing volume of the total brain was measured by point counting as described in Williams (2000). All volume data have been corrected for shrinkage, case-by-case. The correlation between weight and volume from two different sets of BXD animals is 0.66 ( $\mathrm{df}=31 ; p<0.01$ ). Volumetric data used in the results are group means based on 4-6 cases per stain.

Stereological analysis of cell density in the dentate gyrus of BXD strains. Mean cell density in the dentate gyrus was determined bilaterally in an average of five cases of each of 33 BXD strains. For this work we used tissue from the Mouse Brain Library described in the preceding paragraph. All tissue was embedded in celloidin and cut at $30 \mu \mathrm{m}$ in coronal or horizontal planes by Rosen and Williams (2001). Precise volumetric shrinkage for each case had been previously computed as described at www.mbl.org, and this has made it possible to compute the expected density for fixed brain tissue before processing (Table 1). Granule cells, glial cells, and endothelial cells were counted separately using the threedimensional (3-D) counting procedure of Williams and Rakic (1988). Glial cells and endothelial cells make up only a very small fraction of the total cell count $(<10 \%)$ and were relatively easy to distinguish. The volume of the count box was fixed at $17 \times 18 \times 30 \mu \mathrm{m}$ and did not include an upper guard space. The $z$-axis was monitored using a calibrated rotary shaft encoder as described in Williams and Rakic (1988). This modification of the 3-D counting protocol avoids potential bias introduced by differential $z$-axis shrinkage (Hatton and von Bartheld, 1999; von Bartheld, 1999). The sample volume was counted using a contrast-enhanced video differential interference contrast system and a 1.25 NA $100 \times$ planachromat objective. Final magnification on the monitor was $4000 \times$. All cell density estimates are corrected case-by-case for volumetric shrinkage.

We computed the mean neuron density in the granule cell layer at a consistent location $2.0-2.3 \mathrm{~mm}$ posterior to bregma, at a level that corresponds to the central part of the dorsal lateral geniculate nucleus (Fig. 1b). The counting boxes were located in the dorsomedial apex. For each RI strain the mean cell density estimate is based on 10 counts from five individuals. These density estimates have a very low coefficients of error $\left(3 \%\right.$ or 60,000 cells $\left./ \mathrm{mm}^{3}\right)$ across cases within strains. Given this single point sampling protocol, it was of interest to assess how representative values obtained at $-2.0 \mathrm{AP}$ are of the entire dentate gyrus. For a subset of five cases (three C57BL/6J and two DBA/2J cases) we explored this question by performing high-density sampling of sections spaced at $300 \mu \mathrm{m}$ intervals in coronal and horizontal planes. An average of 70 fields were counted using a systematic random protocol (Howard and Reed, 1998). Cell densities tend to be higher in the rostral and dorsal regions than in the caudal temporal region. The difference between extreme poles is $\sim 40 \%$. The gradient of cell density across the granule cell layer is more modest. The marginal part the granule cell layer (both molecular and hilar sides) has a density that is $\sim 10-20 \%$ lower than that 
Table 1. Summary of key hippocampal values in BXD recombinant inbred strain

\begin{tabular}{|c|c|c|c|c|c|c|c|c|c|c|}
\hline Strain & $\begin{array}{l}\text { Case } \\
\mathrm{N}\end{array}$ & $\begin{array}{l}\text { Bilateral } \\
\text { weight } \\
\text { hippocam- } \\
\text { pus (mg) } \\
\pm \text { SE cor- } \\
\text { rected }^{a}\end{array}$ & $\begin{array}{l}\text { Bilateral } \\
\text { weight } \\
(\mathrm{mg})^{b}\end{array}$ & $\begin{array}{l}\text { Granule } \\
\text { cells per } \\
\mathrm{mm}^{3} \\
\times 10^{3}\end{array}$ & $\begin{array}{l}\text { Granule } \\
\text { cells } \mathrm{n} \\
\times 10^{3 c}\end{array}$ & $\begin{array}{l}\text { Brain } \\
\text { weight } \\
(\mathrm{mg})^{d}\end{array}$ & $\begin{array}{l}\text { D1 } \\
\text { Mit145 } \\
89 \mathrm{cM}^{e} \\
\text { Geno- } \\
\text { type }\end{array}$ & $\begin{array}{l}\text { D1 } \\
\text { Mit218 } \\
67 \mathrm{cM}^{e} \\
\text { Geno- } \\
\text { type }\end{array}$ & $\begin{array}{l}\text { D5 } \\
\text { Mit197 } \\
36 \mathrm{cM}^{e} \\
\text { Geno- } \\
\text { type }\end{array}$ & $\begin{array}{l}\mathrm{D} 5 \\
\text { Mit352 } \\
20 \mathrm{cM}^{e} \\
\text { Geno- } \\
\text { type } \\
\end{array}$ \\
\hline BXD1 & 3 & $27.5 \pm 0.3$ & 27.6 & 1040 & 1067 & 433 & B & B & B & B \\
\hline BXD2 & 3 & $25.8 \pm 0.4$ & 24.9 & 849 & 639 & 419 & $\mathrm{~B}$ & B & $\mathrm{D}$ & $\mathrm{D}$ \\
\hline BXD5 & 6 & $25.2 \pm 0.6$ & 29.9 & 859 & 835 & 544 & $\mathrm{D}$ & $\mathrm{D}$ & $\mathrm{D}$ & $\mathrm{D}$ \\
\hline BXD6 & 11 & $28.3 \pm 0.4$ & 26.7 & - & - & 386 & $\mathrm{~B}$ & $\mathrm{D}$ & $\mathrm{B}$ & $\mathrm{B}$ \\
\hline BXD8 & 6 & $26.5 \pm 0.7$ & 28.7 & 974 & 1155 & 477 & B & B & B & B \\
\hline BXD9 & 10 & $25.1 \pm 0.4$ & 25.7 & 936 & 708 & 448 & $\mathrm{D}$ & B & $\mathrm{D}$ & $\mathrm{B}$ \\
\hline BXD11 & 11 & $25.9 \pm 0.1$ & 25.2 & 756 & 793 & 415 & $\mathrm{D}$ & $\mathrm{D}$ & $\mathrm{B}$ & $\mathrm{D}$ \\
\hline BXD12 & 5 & $25.7 \pm 0.5$ & 26.7 & 985 & 887 & 453 & B & B & $\mathrm{D}$ & $\mathrm{B}$ \\
\hline BXD13 & 10 & $25.5 \pm 0.2$ & 23.5 & 850 & 864 & 384 & $\mathrm{D}$ & $\mathrm{D}$ & $\mathrm{B}$ & $\mathrm{B}$ \\
\hline BXD14 & 12 & $26.7 \pm 0.3$ & 26.4 & 880 & 1019 & 412 & B & B & B & B \\
\hline BXD15 & 6 & $25.8 \pm 0.6$ & 26.2 & 907 & 766 & 447 & $\mathrm{D}$ & $\mathrm{D}$ & B & B \\
\hline BXD16 & 10 & $27.1 \pm 0.4$ & 28.1 & 892 & - & 455 & B & B & $\mathrm{D}$ & $\mathrm{D}$ \\
\hline BXD18 & 10 & $25.8 \pm 0.5$ & 26.0 & 1010 & 800 & 435 & $\mathrm{~B}$ & B & $\mathrm{B}$ & $\mathrm{B}$ \\
\hline BXD19 & 10 & $28.1 \pm 0.3$ & 28.0 & 954 & 1002 & 436 & $\mathrm{~B}$ & B & $\mathrm{D}$ & $\mathrm{D}$ \\
\hline BXD20 & 7 & $26.0 \pm 0.8$ & 24.3 & 921 & 709 & 399 & $\mathrm{~B}$ & $\mathrm{D}$ & $\mathrm{D}$ & $\mathrm{D}$ \\
\hline BXD21 & 11 & $25.9 \pm 0.2$ & 25.6 & - & - & 429 & B & B & $\mathrm{D}$ & B \\
\hline BXD22 & 5 & $24.0 \pm 0.2$ & 24.5 & 928 & 960 & 441 & $\mathrm{D}$ & B & $\mathrm{D}$ & $\mathrm{D}$ \\
\hline BXD23 & 5 & $24.7 \pm 0.6$ & 24.5 & 828 & 725 & 435 & $\mathrm{D}$ & $\mathrm{D}$ & $\mathrm{D}$ & B \\
\hline BXD24 & 8 & $23.8 \pm 0.6$ & 21.6 & 1053 & 766 & 388 & $\mathrm{D}$ & $\mathrm{D}$ & $\mathrm{D}$ & $\mathrm{D}$ \\
\hline BXD25 & 9 & $24.8 \pm 0.3$ & 23.7 & 782 & 966 & 412 & $\mathrm{D}$ & B & $\mathrm{B}$ & $\mathrm{B}$ \\
\hline BXD27 & 10 & $25.6 \pm 0.4$ & 22.9 & 837 & 684 & 373 & $\mathrm{D}$ & $\mathrm{D}$ & B & B \\
\hline BXD28 & 10 & $24.9 \pm 0.2$ & 24.1 & 932 & 742 & 415 & $\mathrm{D}$ & $\mathrm{D}$ & $\mathrm{D}$ & $\mathrm{D}$ \\
\hline BXD29 & 6 & $24.8 \pm 0.3$ & 23.3 & 900 & 645 & 403 & $\mathrm{D}$ & $\mathrm{D}$ & B & $\mathrm{B}$ \\
\hline BXD30 & 5 & $23.9 \pm 0.2$ & 21.3 & 905 & 734 & 367 & $\mathrm{D}$ & $\mathrm{D}$ & $\mathrm{D}$ & $\mathrm{D}$ \\
\hline BXD31 & 5 & $24.7 \pm 0.2$ & 23.7 & 860 & 700 & 409 & $\mathrm{~B}$ & B & $\mathrm{D}$ & $\mathrm{D}$ \\
\hline BXD32 & 10 & $23.5 \pm 0.5$ & 24.1 & 970 & 809 & 444 & $\mathrm{D}$ & $\mathrm{D}$ & $\mathrm{D}$ & $\mathrm{D}$ \\
\hline BXD33 & 5 & $27.4 \pm 0.2$ & 26.7 & 822 & 760 & 427 & $\mathrm{D}$ & $\mathrm{D}$ & B & B \\
\hline BXD34 & 5 & $25.0 \pm 0.1$ & 24.4 & 850 & 533 & 420 & $\mathrm{D}$ & $\mathrm{D}$ & $\mathrm{D}$ & $\mathrm{D}$ \\
\hline BXD35 & 6 & $27.3 \pm 0.5$ & 26.4 & 897 & 772 & 413 & $\mathrm{~B}$ & $\mathrm{D}$ & B & $\mathrm{B}$ \\
\hline BXD36 & 5 & $27.6 \pm 0.2$ & 26.4 & 837 & 664 & 405 & B & B & $\mathrm{D}$ & $\mathrm{D}$ \\
\hline BXD37 & 3 & $25.1 \pm 0.3$ & 23.6 & - & - & 411 & $\mathrm{D}$ & $\mathrm{D}$ & $\mathrm{D}$ & $\mathrm{B}$ \\
\hline BXD38 & 9 & $28.5 \pm 0.3$ & 28.3 & 793 & 718 & 418 & $\mathrm{~B}$ & B & B & $\mathrm{B}$ \\
\hline BXD39 & 5 & $26.7 \pm 0.3$ & 25.3 & 793 & 776 & 405 & $\mathrm{D}$ & $\mathrm{D}$ & $\mathrm{D}$ & B \\
\hline BXD40 & 7 & $30.8 \pm 0.3$ & 30.8 & 853 & 995 & 438 & B & B & B & $\mathrm{B}$ \\
\hline BXD42 & 5 & $27.5 \pm 0.2$ & 28.2 & 748 & 794 & 443 & B & B & $\mathrm{D}$ & $\mathrm{D}$ \\
\hline $\mathrm{C} 57 \mathrm{BL} / 6 \mathrm{~J}$ & 13 & $27.4 \pm 0.3$ & 28.4 & 857 & $886^{c}$ & 496 & B & B & B & B \\
\hline $\mathrm{DBA} / 2 \mathrm{~J}$ & 24 & $26.4 \pm 0.3$ & 23.0 & 871 & $697^{c}$ & 415 & $\mathrm{D}$ & $\mathrm{D}$ & $\mathrm{D}$ & $\mathrm{D}$ \\
\hline Average & 8 & $26.1 \pm 0.4$ & 25.7 & 889 & 806 & 426 & & & & \\
\hline
\end{tabular}

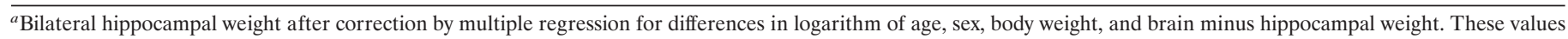
were used for QTL mapping. All cases were adjusted to that of 75-d-old 22 gm female mice with a brain weight of 420 mg.

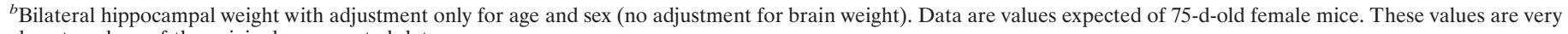
close to values of the original uncorrected data.

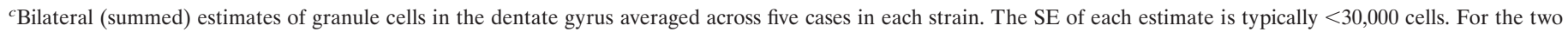

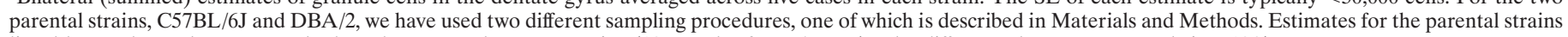
listed here rely on the same method used to count the BXD strains (10 samples from 5 cases). The difference between protocols is $<10 \%$.

${ }^{d}$ Brain weight is the average of the particular sample used for hippocampal dissection.

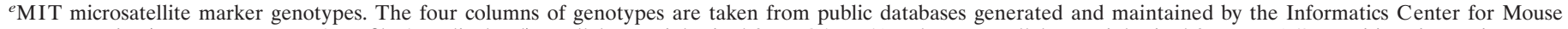

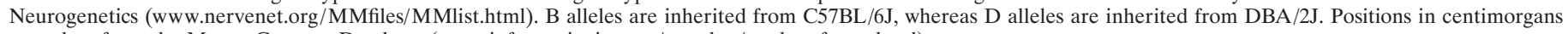
are taken from the Mouse Genome Database (www.informatics.jax.org/searches/marker_form.shtml).

of the most central part the granule cell layer. The sampling sites that we selected for analysis are intermediate in both position and in mean cell density and yield good estimates of total granule cell number. For example, comprehensive estimates of granule cell number from three C57BL/6J mice obtained using a dense sampling grid (60-80 samples per side) are 484,000 $\pm 16,000,465,000 \pm 16,000$, and 435,000 $\pm 16,000$. This gives a unilateral average of 456,000 granule cells. In comparison, the estimate given in Table 1 that is based on counts from five cases and 10 bilateral samples taken at AP -2 is 443,000 with an SE of $\sim 15,000$ (note that the estimates in Table 1 are given for the sum of both sides and for comparison were divided by two). Our estimate for this strain is close to that recently obtained by Abusaad et al. (1999) (493,000 based on six 9-week-old cases also of both sexes). Similarly, the two comprehensive estimates of the other parent, DBA/2J, were 360,000 $\pm 11,000$ and 


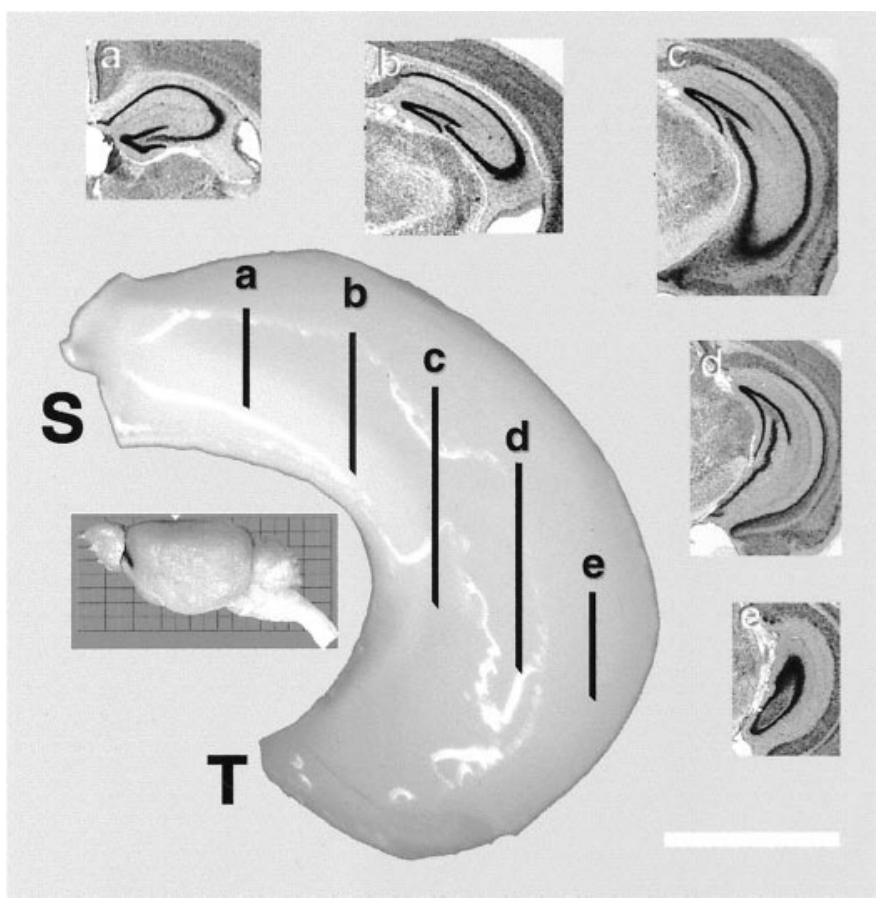

Figure 1. An example of a dissected hippocampus. This dissection is from the left hemisphere and is oriented properly with respect to the septotemporal ( $S$ to $T$ ) axis of the small inset of a mouse brain. The internal anatomy of the hippocampus is referenced by five small insets of Nissl-stained sections in the coronal plane $(a-e)$. Scale bar (for the image of the dissected hippocampus), $1 \mathrm{~mm}$.

$312,000 \pm 8,000$. This compares to a mean of 349,000 cells in Table 1 . The agreement is satisfactory, and estimates listed in Table 1 are of sufficient accuracy to gauge effects of the two Hipp loci on dentate granule cell populations.

Regression analysis. Complex trait analysis tests the strength of the relationships between genotypes and phenotypes. The advantages and restrictions of this biometric approach have been reviewed extensively (Tanksley, 1993; Lander and Schork, 1994; Lynch and Walsh, 1998). One issue that is important in our analysis of the hippocampus is the specificity of gene effects. We did not want to inadvertently map genes that control body or brain weight. For this reason we have performed linear regression analysis to explore and statistically control for covariance between hippocampal weight and other variables using standard techniques explained more fully elsewhere (Sokal and Rohlf, 1995; Williams, 2000). For example, strain BXD5 has an unusually large brain $(544 \mathrm{mg})$ and, not surprisingly, has an unusually large hippocampus $(30 \mathrm{mg})$. However, after normalizing for brain weight with regression, a process that involves computing residual hippocampus size, the hippocampus of this strain is not at all exceptional. Computing residuals via regression is preferable to the use of ratios to correct for brain or body size effects. Use of ratios can lead to biased results (Lynch and Walsh, 1998, p. 307; Bishop and Wahlsten, 1999). Controlled parameters in our multiple linear regression analysis include brain weight, sex, age, and body weight. Interactions and second-order terms were not significant. The standard assumptions required for regression analysis were met. Statistics and statistical tests were computed using Data Desk (Data Description, Inc., Ithaca NY; www.datadesk.com).

Genotyping and QTL mapping. In essence, the QTL mapping involves categorizing cases or strains (genetic individuals) based on their genotypes (e.g., $B B, B D$, or $D D$ ) at defined chromosomal markers (e.g., microsatellite loci) and comparing these groups with a quantitative variable; in our case hippocampal measurements (Table 1). A gene locus that affects hippocampus will be recognized when the variation in phenotype is well matched to differences in genotype (see www.nervenet. org/papers/brainrev99.html for several examples). QTL mapping generally proceeds from an analysis at defined loci (single marker analysis), to an analysis at positions inferred between loci (simple interval mapping), and then finally to positions inferred between loci but with statistical control for background loci of interest (composite interval mapping). The QTL analysis program, Map Manager QT (Manly and Olson, 1999), implements both simple and composite interval mapping methods described by Haley and Knott (1992) and evaluates genotype-phenotype associations with likelihood statistics and permutation tests. Genomewide significance levels for assessing the confidence of the linkage statistics are estimated by comparing the peak likelihood ratio statistic (LRS) of correctly ordered data sets with LRSs computed for 10,000 permutations (Churchill and Doerge, 1994). Permutation tests are a commonly accepted method for determining the probability of the effect occurring by chance. LRS scores can be converted to logarithm of odds ratios (LOD scores) by dividing by 4.6.

Genomic DNA from all F2 mice was extracted from their spleens using a high-salt procedure (Laird et al., 1991; www.nervenet.org/papers/ ShortCourse98.html). A set of 145 microsatellite loci distributed across all autosomes and the $\mathrm{X}$ chromosome were typed in the $\mathrm{F} 2$ progeny using a modified version of the protocol of Love et al. (1990) and Dietrich et al. (1992). Each $10 \mu$ l PCR reaction contained $1 \times$ PCR buffer, $1.92 \mathrm{~mm}$ $\mathrm{MgCl}_{2}, 0.25 \mathrm{U}$ of $\mathrm{Taq}$ DNA polymerase, $0.2 \mathrm{~mm}$ of each deoxynucleotide, $132 \mathrm{~nm}$ of the primers, and $50 \mathrm{ng}$ of genomic DNA. The microsatellite primer pairs were purchased from Research Genetics (Huntsville, AL; www.resgen.com). A loading dye (60\% sucrose, $1.0 \mathrm{~mm}$ cresol red) was added to the reaction before the PCR (Routman and Cheverud, 1994). PCRs were performed in 96-well microtiter plates. We used a highstringency touchdown protocol in which the annealing temperature was lowered progressively from 60 to $50^{\circ} \mathrm{C}$ in $2^{\circ} \mathrm{C}$ steps over the first six cycles (Don et al., 1991). After 30 cycles, PCR products were run on $2.5 \%$ Metaphor agarose gels (FMC Bioproducts, Rockland ME), stained with ethidium bromide, and photographed. Genotypes were entered into Microsoft Excel 98 and transferred to Map Manager QT (Manly, 1993; Manly and Olson, 1999) for mapping and permutation analysis. For mapping with the BXD set we used a set of $\sim 831$ fully typed loci. We took 200 genotypes from Taylor et al. (1999), and the remaining 630 genotypes were generated for this analysis in our laboratory using the same methods described above for the F2. The new genotypes are available from the Informatics Center for Mouse Neurogenetics (www.nervenet.org/MMfiles/MMlist.html).

\section{RESULTS}

The results are divided into two main sections. The first is a biometric study and multiple regression analysis of normal variation in the size of the hippocampus as a function of sex, age, brain weight, and body weight. We initially focus on hippocampal weights of all BXD strains (Table 1), 180 F2 progeny, two parental strains, and the reciprocal F1 hybrids. This is followed by an analysis of the absolute and relative volumes of four parts of the hippocampus and a stereological analysis of granule cells in the dentate gyrus of BXD strains. The second main section summarizes our QTL mapping results and describes the effects of two QTLs on hippocampal weight, structure, and granule cell number. A key part of this work is an analysis of the specificity of action of these QTLs. The multiple regression analysis ensures that the QTLs that we have mapped have comparatively selective (although not exclusive) effects on the size, structure, and cell populations of the hippocampus.

\section{Normal variation in size, structure, and cell number Hippocampal weights of parental strains}

Hippocampal weights of the parental strains B6 and D2 are $28.4 \pm 0.7$ and $23.0 \pm 0.3 \mathrm{mg}$, respectively (Table 1). This $19 \%$ difference is highly significant $\left(t_{20}=17.0 ; p<0.001\right)$ and corresponds to a $20 \%$ difference in number of granule cells in the dentate gyrus of these two strains (Table 1). Total brain weight of B6 is also $\sim 20 \%$ greater than that of D2 (496 $\pm 6 \mathrm{mg}$ versus $415 \pm 4 \mathrm{mg})$, whereas body weight is $\sim 28 \%$ greater at $75 \mathrm{~d}(24.7$ versus $19.3 \mathrm{gm})$. When hippocampal weights of these strains are adjusted to account for differences in brain and body weight, the strain difference is reduced to $1 \mathrm{mg}$ : $27.4 \pm 0.3$ versus $26.4 \pm 0.3$ (Table 1, column 3). This difference is still statistically significant 


\begin{tabular}{|c|c|c|c|c|c|c|c|c|c|c|}
\hline & Hipp & Lage & Age & Sex & Body & Brain & Brain-Hipp & Forebrain & FB-Hipp & Cerebellum \\
\hline Hipp & - & 9 & 4 & 1 & 18 & 53 & 47 & 52 & 45 & 31 \\
\hline Lage & 0.30 & - & 75 & 1 & 48 & 12 & 11 & 5 & 5 & 18 \\
\hline Age & 0.20 & 0.86 & - & 1 & 21 & 6 & 6 & 2 & 2 & 6 \\
\hline $\operatorname{Sex}(F=1)$ & -0.09 & 0.07 & 0.07 & - & 3 & 0 & 0 & 0 & 0 & 0 \\
\hline Body & 0.42 & 0.69 & 0.46 & -0.17 & - & 27 & 27 & 18 & 17 & 26 \\
\hline Brain & 0.73 & 0.34 & 0.25 & 0.00 & 0.52 & - & 100 & 89 & 88 & 49 \\
\hline Brain-Hipp & 0.69 & 0.34 & 0.25 & 0.01 & 0.52 & 0.99 & - & 88 & 88 & 48 \\
\hline Forebrain & 0.72 & 0.23 & 0.14 & 0.01 & 0.43 & 0.94 & 0.94 & - & 99 & 44 \\
\hline FB-Hipp & 0.67 & 0.21 & 0.13 & 0.03 & 0.42 & 0.94 & 0.94 & 0.99 & - & 43 \\
\hline Cerebellum & 0.56 & 0.43 & 0.25 & 0.00 & 0.51 & 0.70 & 0.69 & 0.67 & 0.66 & - \\
\hline
\end{tabular}

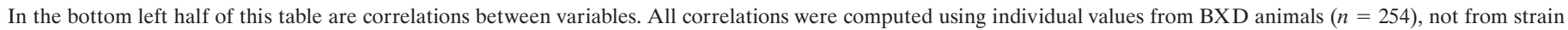
averages. These values are therefore typical of what would be obtained from a mixed or genetically heterogeneous population of animals. In the upper right half are coefficients of determination $\left(R^{2}\right)$ expressed as percentages.

Correlations greater than 0.138 are significant $(p<0.05)$. Correlations $>0.181$ are significant $(p<0.01)$.

Hipp, Hippocampus; FB, forebrain; Lage, logarithm of age.

$\left(t_{24}=17.0 ; p=0.04\right)$. The hippocampal weight of the reciprocal F1 hybrids-BDF1 and DBF1-are $27.8 \pm 0.3$ and $28.2 \pm 0.4 \mathrm{mg}$, respectively, an insignificant difference from each other or from the B6 parent.

\section{Brain weight and hippocampal weight}

Variation in brain weight is the single most important predictor of variation in hippocampal weight $(r=0.73)$ (Table 2$)$, and $50 \%$ of the variance in hippocampal size among individual BXD mice can be accounted for by the simple regression equation: hippocampal weight $=4.08+0.05$ (brain weight in milligrams). Brain weight includes the hippocampus and to compare fully independent variables, we recomputed this relation after subtracting hippocampal weight from that of the brain. Although the slope is almost precisely the same, the amount of variance explained by the equation is reduced by $5.0 \%$ (Fig. 2a, $b$, Table 2). Among the F2 sample, variation in brain weight is also the most important predictor of variation in hippocampal weight: $57 \%$ of variance in hippocampal weight is accounted for by brain weight, whereas $51 \%$ is accounted for by brain minus hippocampus.

\section{Body weight and hippocampal weight}

Body weight and hippocampal weight are correlated among BXD mice $(r=0.42)$ (Table 2). A $1 \mathrm{gm}$ increase in body weight is associated with a $0.19 \pm 0.03 \mathrm{mg}$ increase in hippocampal weight (Fig. 2c). However, there is no significant correlation when brain weight is used as a cofactor in a multiple regression analysis (Fig. $2 d$ ). In F2 mice body weight correlates even more weakly with hippocampus $(r=0.23)$, and variation in body weight accounts for only $5 \%$ of variation in hippocampal weight. A $1 \mathrm{gm}$ increase in body weight is associated with a $0.10 \pm 0.03 \mathrm{mg}$ increase in hippocampal weight.

\section{Age and hippocampal weight}

The weight of the hippocampus increases with age. Among BXD individuals that ranged in age from 30 to $300 \mathrm{~d}$, the slope of this increase is $3.4 \mathrm{mg}(\sim 15 \%)$ for a 10 -fold increase in age. Mice are sexually mature by $50 \mathrm{~d}$ of age, and over the next $200 \mathrm{~d}$ the summed weight of the hippocampi increases by $2.5 \mathrm{mg}$, or close to $10 \%$. Variation in age among BXD mice accounts for $9 \%$ of the variance in hippocampal weight.

In the BXD animals the weights of both the forebrain and hippocampus increase with age. However, the effect of age on the hippocampus is not explained completely by an increase in forebrain weight. The slope of the regression of hippocampus against age remains significant $\left(t_{247}=4.0 ; p<0.0001\right)$ but decreases from 3.9 to $2.2 \pm 0.5 \mathrm{mg} / \mathrm{log}$ age when forebrain weight is added as a cofactor (Fig. 2e). For the sample of F2 progeny there is a significant upward trend in hippocampal weight between 75 and $150 \mathrm{~d}$ that amounts to $\sim 0.02 \mathrm{mg} / \mathrm{d}\left(R^{2}=3 \%\right.$; $\left.p<0.05\right)$. In contrast to the BXD sample, there is no greater proportional increase in hippocampal weight of the F2 sample than in the remainder of the forebrain.

\section{Sex and hippocampal weight}

Hippocampi of male mice typically weigh $0.5-0.6 \mathrm{mg}$ more than those of females in both BXD mice $\left(t_{247}=2.3 ; p=0.02\right)$ and F2 $\left(t_{176}=2.8 ; p=0.005\right)$ intercrosses (Fig. $\left.2 f\right)$. Despite differences in body weight, male and female mice have almost precisely the same average fixed brain weights $-422.7 \pm 3.9$ and $422.8 \pm 3.0$ $\mathrm{mg}$, respectively, for the BXD sample. The difference in hippocampal weight is therefore a sex-specific difference. Although statistically significant, the $2 \%$ mean difference between sexes is relatively small given the other numerous sources of variance. This difference cannot be characterized as a sexual dimorphism-sex accounts for only $2 \%$ of the total variance in hippocampal weight.

\section{Comparison of right and left hippocampi}

Measured differences in weights of right and left hippocampi are attributable to biological differences and technical error. The mean difference between the two sides averages $0.3 \mathrm{mg}$. After a correction for small $n$, this corresponds to a right-left coefficient of variation of merely 2\% (Gurland and Tripathi correction; Sokal and Rohlf, 1995). This value sets an upper limit on the magnitude of variation generated by developmental noise and the magnitude of error introduced by fixation and dissection technique. The mean weights of right and left hippocampi across all BXD and F2 mice differ by only $0.05 \mathrm{mg}$. The right side is on average $0.4 \%$ heavier. This tiny difference does reach statistical significance (paired $t_{430}=2.4 ; p=0.012$ ), but it is possible that a slight technical bias is introduced during dissection.

\section{Multiple linear regression analysis}

To map QTLs that have specific effects on the hippocampus-as opposed to whole brain weight and other variables-we corrected 
Figure 2. Regression analysis of hippocampal weight (bilateral sum). $A$, Approximately half of the variation in hippocampal weight is associated with variation in brain weight. $B$, Corresponding plot of hippocampal weight against brain weight minus hippocampal weight. $C$, Body weight is significantly correlated with hippocampal weight. As shown in $D$, after correction for brain weight by multiple linear regression, body weight residuals (Body Res) have no independent association with hippocampal residual weight (Hippocampus Res). $E, x$ and $y$ axes represent the logarithm of age residuals ( $\log$ age Res) and hippocampus residuals (Hippocampus Res), respectively. F, Age remains significantly correlated with hippocampal weight residuals even after accounting for variation in forebrain minus hippocampus (see Results for details on calculation methods). There is a modest sex difference. $m$ is regression line for males; $f$ is regression line for females. See Table 2 for correlations among these and other variables.
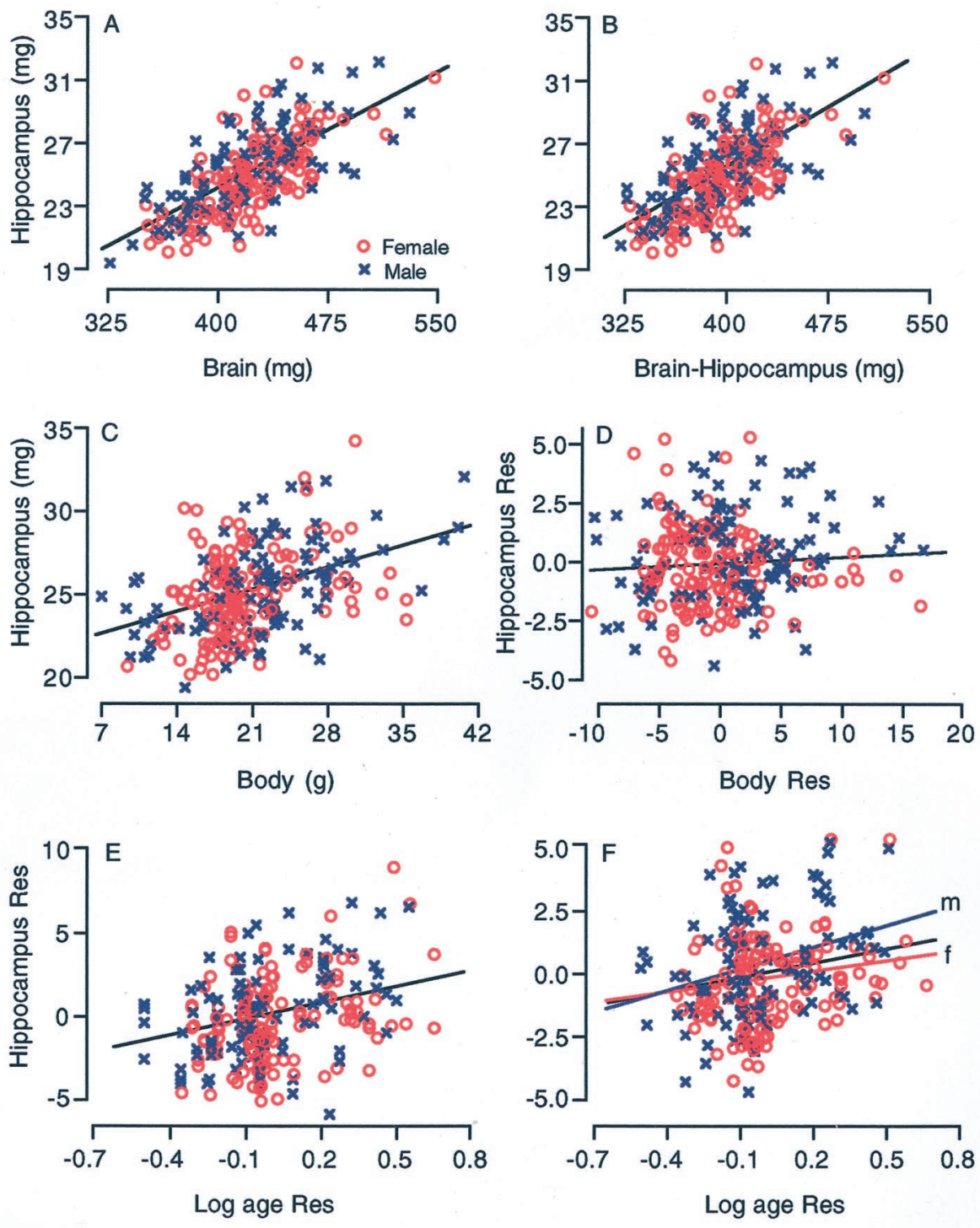

all original hippocampal weight data by multiple linear regression using the equation:

hippocampal weight (bilateral, fixed in milligrams) $=4.57+$ 1.05 (logarithm of age in days) -0.004 (body weight in grams) + 0.048 (brain weight - hippocampal weight in milligrams) -0.56 (if female).

This equation accounts for $\sim 50 \%$ of the variance among BXD cases $\left(F_{(4,246)}=59.5\right)$. We refer to these regression-corrected values as adjusted hippocampal weights (Table 1, column 3 ). The adjusted weights represent the weight of the hippocampus after removing predictable effects of sex, brain size, age, and body size. These corrected values were used for mapping QTLs that have comparatively specific effects on the hippocampus. The adjusted hippocampal weight averages $26.1 \pm 0.4 \mathrm{mg}$ and ranges from a low of $23.5 \mathrm{mg}$ in BXD32 to a high of $30.8 \mathrm{mg}$ in BXD40. This range extends below the adjusted value of the parental strain DBA/2J (26.4 mg) and far above the value of parental strain C57BL/6J (27.4 mg). A similar multiple linear regression model was used to create a set of adjusted values for the F2 mice:

hippocampal weight (fixed in milligrams) $=2.81-1.35$ (logarithm of age in days) +0.017 (body weight in grams) +0.063 (brain weight - hippocampal weight in milligrams) -0.52 (if female).

This equation accounts for $\sim 53 \%$ of the variance among the $\mathrm{F} 2$ sample $\left(F_{(4,175)}=50.2\right)$. The mean of the adjusted weights for the $\mathrm{F} 2$ mice was $26.7 \pm 0.1 \mathrm{mg}$.

\section{Heritability of hippocampal weight variation}

Heritability of hippocampal weight computed using the method of Hegmann and Possidente (1981) was $44 \%$ for unadjusted hippocampal weight and $51 \%$ for adjusted weight in the BXD sample. The corresponding estimate of heritability derived by comparing the variance of $\mathrm{F} 1$ and $\mathrm{F} 2$ animals is $35 \%$.

\section{Volumetric analysis of the hippocampus}

The volume of the hippocampus and several components were estimated to screen for possible strain differences and to assess specificity of gene effects. Regions that were measured include the whole hippocampal formation (a measure that corresponds to hippocampal weight; see Materials and Methods), the hippocampus proper (excluding the dentate gyrus), the pyramidal cell layer of CA1 through CA3, the dentate gyrus, and the granule cell layer 
A
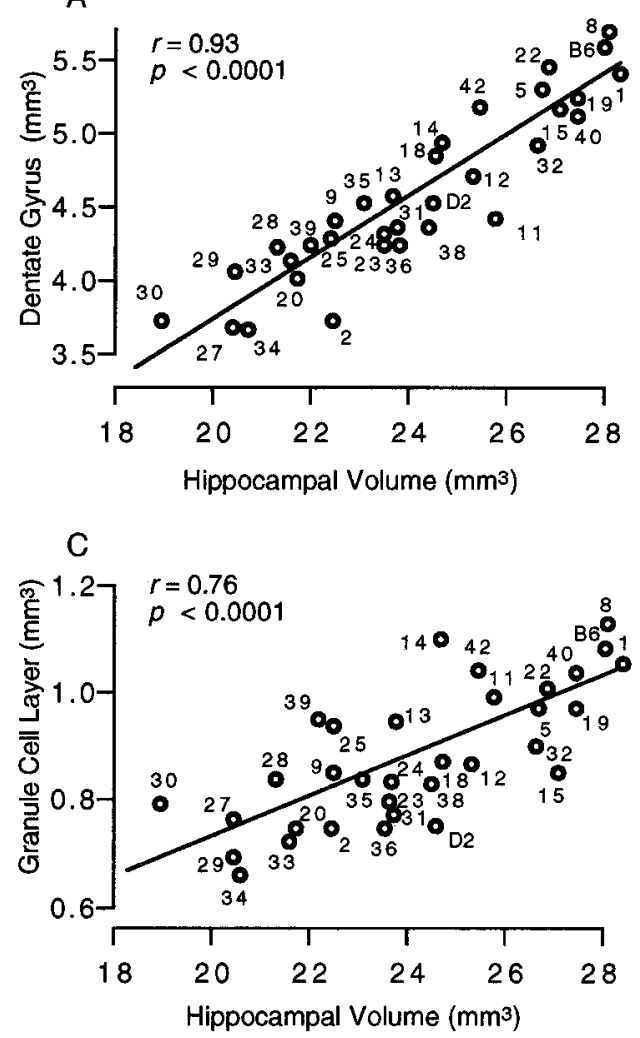

B
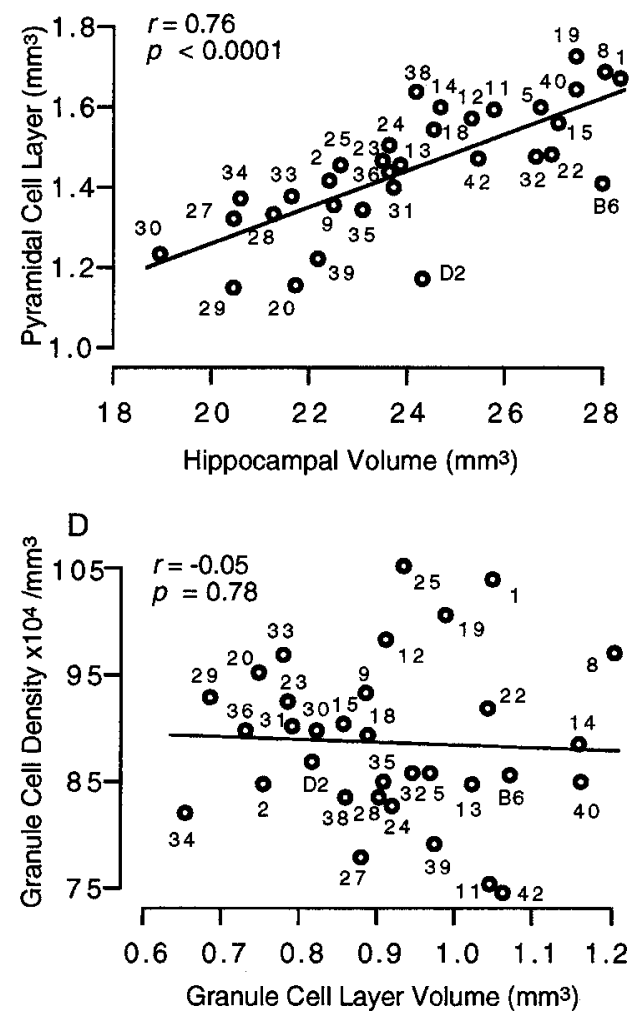

Figure 3. Relations between volume of hippocampus and $(A)$ volume of the entire dentate gyrus, $(B)$ volume of the pyramidal cell layer, including CA1 through $\mathrm{CA} 3$, and $(C)$ the volume of the granule cell layer of the dentate gyrus. $D$ illustrates the relation between granule cell layer volume and granule cell density. All volumetric data are corrected for differential shrinkage. of the dentate gyrus. We find significant differences among BXD and parental strains for each hippocampal component: the total hippocampal complex $\left(R^{2}=54 \% ; F_{(32,135)}=5 ; p<0.0001\right)$, the hippocampus proper $\left(R^{2}=53.6 \% ; F_{(32,135)}=4.9 ; p<0.0001\right)$, the dentate gyrus $\left(R^{2}=53 \% ; F_{(32,135)}=4.8 ; p<0.0001\right)$, the granule layer $\left(R^{2}=44 \% ; F_{(32,135)}=3.3 ; p<0.0001\right)$, and the pyramidal layer $\left(R^{2}=51 \% ; F_{(32,135)}=4.4 ; p<0.0001\right)$. We also find that the volume of each part correlates significantly with the volume of the total hippocampus. Correlations range from 0.76 to 0.93 (Fig. 3). An interesting aspect of this work is that the relative size of the four components differ appreciably among strains. For example, the volume of the dentate gyrus in strains that have almost precisely the same total hippocampal volume ranges from $3.7 \mathrm{~mm}^{3}$ to $4.5 \mathrm{~mm}^{3}$ (Fig. 3a, see BXD2 and BXD9). Similarly, the pyramidal cell volume ranges from $1.1 \mathrm{~mm}^{3}$ to $1.7 \mathrm{~mm}^{3}$ among strains with essentially the same hippocampal volume (Fig. 3b).

\section{Stereological analysis of the dentate granule cell layer}

The average packing density of granule cells in the dentate gyrus of BXD RI strains ranges from 750,000 to $1,050,000$ cells $/ \mathrm{mm}^{3}$. SEs of these estimates are generally low and average 60,000 cells $/ \mathrm{mm}^{3}$. Variation in density is not correlated with the total volume of whole brain, the hippocampus, the dentate gyrus, or even the volume of the granule cell layer itself (Fig. $3 d$ ). However, in the two parental strains there is a good correspondence between estimates of granule cell number and the weight of the hippocampus (Table 1). Similarly, there is a significant correlation between estimates of granule cell number and dentate gyrus volume and total hippocampal volume $(r=0.77$ and 0.70 , respectively). Bilateral estimates of cell number range from over 1,000,000 cells in BXD1, BXD8, BXD14, and BXD19 to under 700,000 in BXD2, BXD27, BXD29, and BXD34 (Table 1). The magnitude of this difference is as great as differences in retinal ganglion cell number among BXD strains (Williams et al., 1998).

\section{QTL analysis of the mouse hippocampus Mapping QTLs using BXD mice}

Among the BXD strains we detected an excellent match between variation in hippocampal weight and the distribution of $B$ and $D$ alleles at the marker D1Mit145 on distal chromosome (Chr) 1 (Table 1). The average weight for $17 \mathrm{BXD}$ strains with a $B B$ genotype at this locus was $27.04 \pm 0.35 \mathrm{mg}$, whereas that for 18 strains with a $D D$ genotype was $25.08 \pm 0.23 \mathrm{mg}$. A single $B$ allele in this interval on Chr 1 therefore has an additive effect of $\sim+1.0$ $\mathrm{mg}$ on hippocampal weight. The correlation between hippocampal weight and alleles at D1Mit145 is 0.63 (Table 1), suggesting that as much as $40 \%$ of the genetic variance and $15-20 \%$ of the total phenotypic variance is generated by a QTL on Chr 1.

The association between differences in hippocampal weight and alleles on Chr 1 is strong and has an LRS of 19.5 (genomewide $p<0.05$ ), equivalent to an LOD score of 4.2 (Fig. $4 a$ ). The 2-LOD confidence interval, the chromosomal region in which the QTL is located with a confidence of $>95 \%$, is $\sim 35 \mathrm{cM}$ wide and is centered at $82-85 \mathrm{cM}$. We have named this locus Hippocampus 1. The symbol is Hippla.

We controlled for variation generated by the Hippla interval on Chr 1 and searched for secondary QTLs affecting hippocampal weight. This procedure uncovered an interval on Chr 5 that is flanked proximally by D5Mit352 $(20 \mathrm{cM})$ and distally by D5Mit356 $(41 \mathrm{cM})$. The LRS score in this interval peaks at 11.5 (Fig. $4 e$ ). The genome-wide $p$ is 0.24 and falls short of the level needed to declare a QTL. We subsequently verified the position of this Chr 5 QTL and that on Chr 1 with the F2 intercross. 


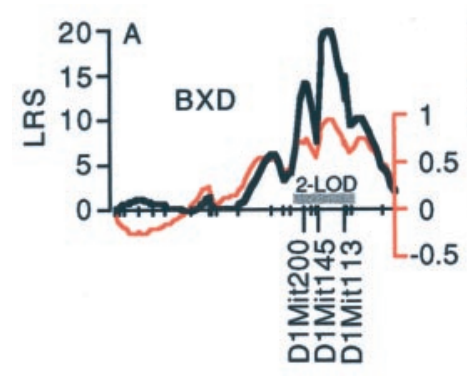

Chr 1 simple mapping

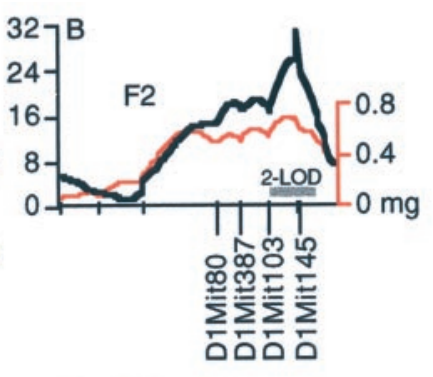

Chr 1 simple mapping

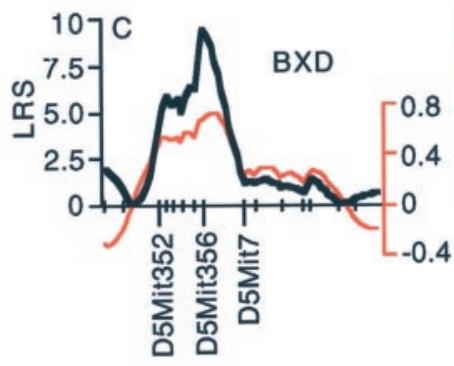

Chr 5 simple mapping

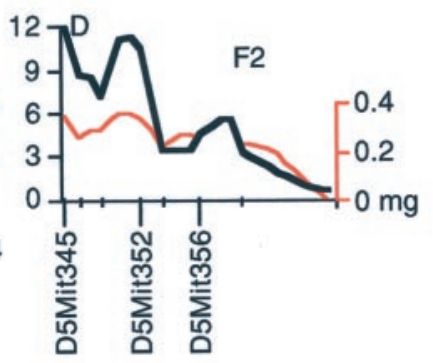

Chr 5 simple mapping

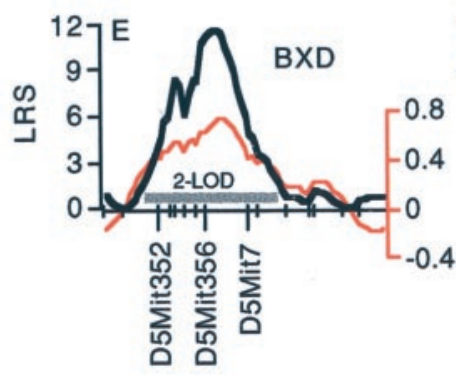

Chr 5 composite mapping

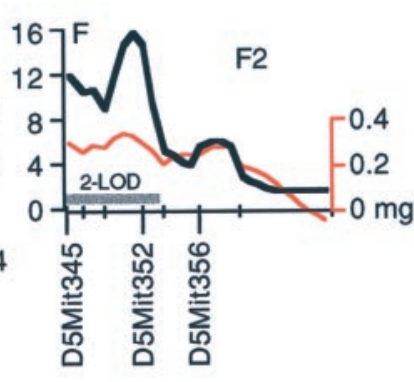

Chr 5 composite mapping
Figure 4. Interval maps of QTL on Chr $1(A, B)$ and Chr $5(C, D, E, F)$ in BXD (left) and F2 (right). In each of the six panels, the left axis and bold black line represent values of the LRS computed at $1 \mathrm{cM}$ intervals. The right axis and the thin red line represent values for the additive effect of the substitution of a single $D$ allele with a $B$ allele. The $x$-axis represents the entire genetic lengths of $\mathrm{Chr} 1(A, B)$ and $\mathrm{Chr} 5(C-F)$. Positions of several markers used for mapping both QTLs (e.g., D1Mit200, D5Mit356) are labeled on the $x$ axes. The approximate 2-LOD confidence band is represented by a gray horizontal bar. $A-D$ are simple interval maps, whereas $E$ and $F$ are composite interval maps that control for the Hipp1a locus (D1Mit145) on Chr 1.

\section{Mapping with the F2 intercross}

The hippocampi of F2 progeny were analyzed to extend and validate the analysis of BXD strains. A linkage between weight of the hippocampus was again discovered on distal Chr 1, with a peak LRS of 34 between marker D1Mit57 and D1Mit145 (Fig. 4b). This linkage statistic is highly significant with a genome-wide $p$ value of 0.0003 . The 2 -LOD confidence interval on Chr 1 is $\sim 25$ $\mathrm{cM}$ wide and extends from 70 to $95 \mathrm{cM}$ and is bracketed by the markers D1Mit103 and D1Mit356. Individuals with $B B, B D$, and $D D$ genotypes at D1Mit145, the key marker locus identified in the BXD data set, have mean adjusted hippocampal weights of $27.43 \pm 0.20 \mathrm{mg}, 26.72 \pm 0.11 \mathrm{mg}$, and $26.16 \pm 0.16 \mathrm{mg}$, respectively. Hippla is responsible for $\sim 14 \%$ of the total phenotypic variance in hippocampal weight. The additive effect of a single $B$-to- $D$ allele substitution is $\sim 0.64 \mathrm{mg}$. This is a slightly more modest effect than that noted in the BXD strains at D1Mit145 (27.04 and $25.08 \mathrm{mg}$ for $B B$ and $D D$ genotypes).

The Hipp $5 a$ locus on proximal Chr 5 was also confirmed using the F2 intercross. This Chr 5 interval has LRS scores of 12.2 at D5Mit345 and 11.8 at D5Mit352 (Fig. 4d). When variation associated with Hippla is controlled, the LRS at D5Mit352 increases to 15.9 (Fig. $4 f$ ). Mean adjusted hippocampal weights of the $B B$, $B D$, and $D D$ genotypes at this marker are $27.3,26.6$, and $26.5 \mathrm{mg}$ (ANOVA $\left.F_{(2,174)}=6.0 ; p=0.003\right)$. When data from BXD and F2 sets are combined, Hipp $5 a$ is most likely to map between 15 and $40 \mathrm{cM}$ on Chr 5 (genome-wide $p<0.05$ ).

\section{Test of epistasis between Hipp1a and Hipp5a}

Effects of Hipp1a and Hipp5a sum almost linearly. BXD strains with $B$ alleles at both loci have hippocampi that weigh $3.1 \mathrm{mg}$ $(12 \%)$ more than those of BXD strains with $D$ alleles. The predicted summed effect is $3.5 \mathrm{mg}$. Residual hippocampal weights for the four possible two-locus genotypes are $1.7 \mathrm{mg}(B / B$ at Hippla/Hipp5a), $0.27(B / D),-0.25(D / B)$, and $-1.4(D / D)$. The same pattern characterizes F2 animals: those with $B$ alleles on both Chr 1 and Chr 5 have hippocampi that weigh $1.92 \mathrm{mg}(7 \%)$ more than those of F2 animals with $D$ alleles. This compares to a predicted linear sum of $2.1 \mathrm{mg}$. The double heterozygote is within $0.1 \mathrm{mg}$ of the mean of all cases. Thus, Hippla and Hipp5a do not appear to interact epistatically to modulate hippocampal size.

\section{Specificity of QTL action}

Hippla is defined as a QTL that modulates total hippocampal weight, but it is possible that this locus has more intense effects on one or more parts of the hippocampus, such as the dentate gyrus. To test this possibility we mapped volumetric data from the independent set of BXD data. The top four panels of Figure 5 $(a-d)$ demonstrate that volumetric data also show linkage to $\mathrm{Chr}$ 1. There is concordance in the locations of peak LRS scores for hippocampal volume (Fig. $5 a$ ), pyramidal cell layer volume (Fig. $5 b)$, granule cell layer volume (Fig. $5 c$ ), dentate gyrus volume (Fig. $5 d$ ), and mossy fiber area (Fig. 5e) (reanalysis of data from Lassalle et al., 1999). The important point is that in all of these maps the LRS peaks between 65 and $85 \mathrm{cM}$, the same interval defined as the location of Hippla in Figure 4 using our more extensive hippocampal weight data set. This is also true of the untransformed and uncorrected cell counts from the dentate gyrus. Peak LRS values for all of these traits have point-wise probabilities $<0.05$, and $<0.001$ in the case of mossy fiber area. There is a similar concordance between the position of Hipp $5 a$ on Chr 5 for weight (Fig. 4) and the peak LRS for volume of total hippocampus, the dentate gyrus, the granule cell layer, and the pyramidal cell layer (Fig. 6). This suggests that Hipp5a also has broad effects on hippocampal structure.

The two Hipp loci contribute to a difference of just over 100,000 cells per dentate gyrus (200,000 bilaterally). Two markers in the Hipp1a and Hipp5a intervals-D1Mit218 and D5Mit197-collectively account for $28 \%$ of the variance in granule cell number among the BXD strains means (Table 1) $\left(F_{(30,2)}=7.1, p=0.007\right.$ at D1Mit218, $p=0.039$ at D5Mit197). It is therefore highly likely that Hipp1a has broad effects on all parts of the hippocampus that we measured, affecting both volume and neuron numbers.

The bottom panels in Figures 5 and 6 illustrate one of the advantages of gene mapping with recombinant inbred strains. Using updated high-density microsatellite maps, we remapped 

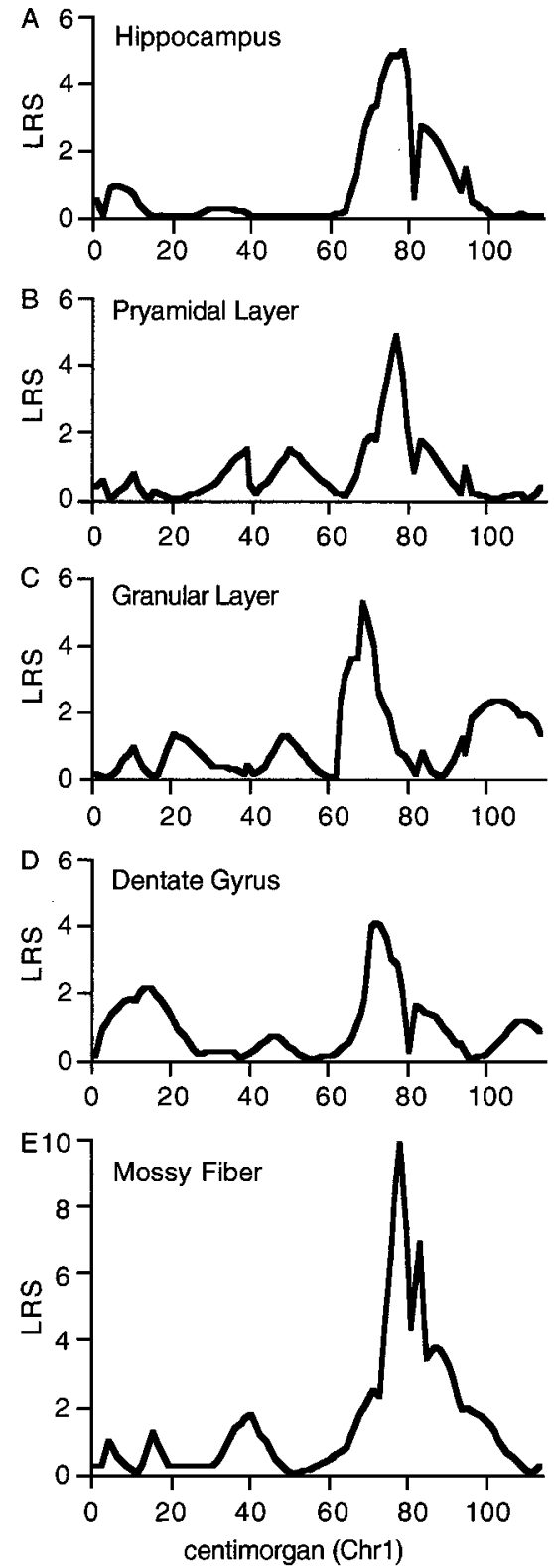

Figure 5. Interval maps for five different hippocampal traits on maps of Chr 1 derived from the BXD strains. The $x$ axes represent the entire genetic length of Chr 1. $y$ axes represent values for the LRS computed at $1 \mathrm{cM}$ intervals. $A$, Hippocampal volume; $B$, pyramidal cell layer volume (CA1-CA3); $C$, granule cell layer volume of the dentate gyrus; $D$, volume of the dentate gyrus (excludes part of the hilus); $E$, cross-section area of the mossy fiber projection (from Lassalle et al., 1999).

data on the area of the mossy fiber projection in BXD strains published by Lassalle et al. (1999). Our remapping demonstrates that Hippla, and possibly Hipp5a, act to control the volume of the mossy fiber projection, a finding not unexpected given the differences in granule cell number.

\section{DISCUSSION}

\section{Synopsis}

We have mapped two gene loci that have pronounced effects on hippocampal structure to chromosomes 1 and 5 in mouse. Hipp 1a and Hipp5a are among the first loci known to generate normal variation in the size of any part of the mammalian forebrain.
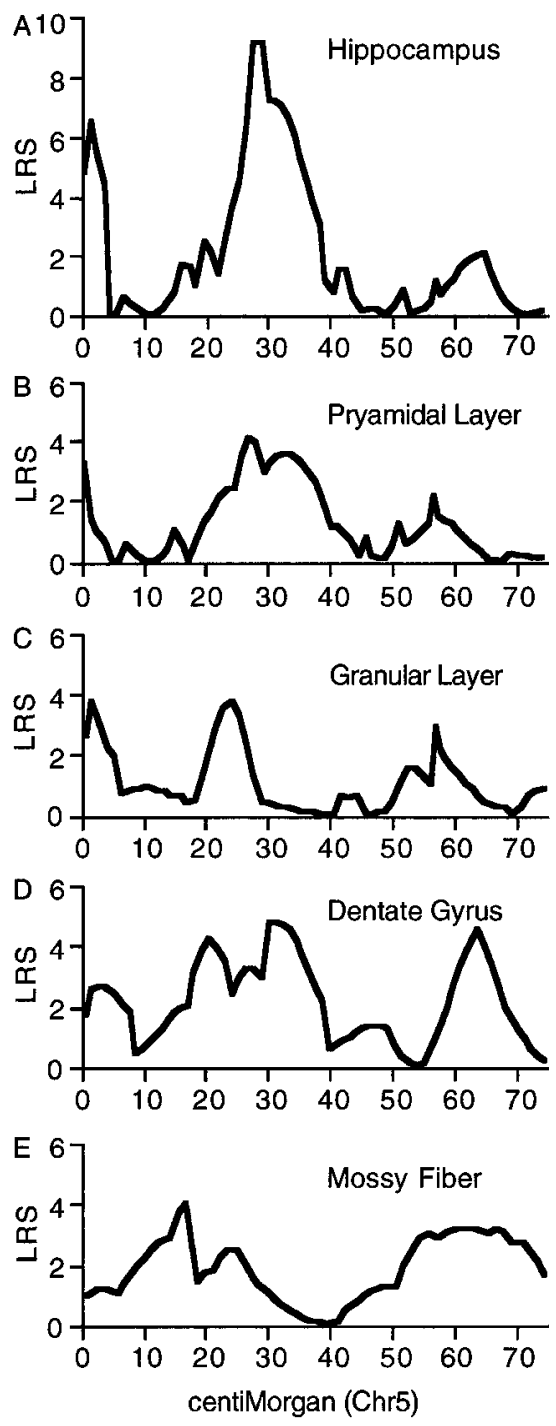

Figure 6. Interval map of QTL on Chr 5. $x$ axes represent the entire genetic length of Chr 5. $y$ axes represent values for the LRS computed at $1 \mathrm{cM}$ intervals. Conventions as in Figure 5.

While effects of QTLs are often modest in comparison to those of targeted gene deletions and spontaneous mutations, these two QTLs have effects that significantly exceed those generated by sex, age, or body weight. It is possible, even likely, that the $10-15 \%$ shifts in hippocampal weight and neuron number associated with these two QTLs have functional consequences. This work represents a key step to characterizing genes that normally modulate proliferation, growth, and maturation of the hippocampus. The volumetric and stereological analyses of the Hipp loci demonstrate that both loci have widespread effects on hippocampal structure, including an effect on at least one well defined hippocampal cell population.

\section{Relations between structure and function}

Differences in the size and structure of the hippocampus are known to be associated with marked differences in development, behavior, and life history. For example, Merriam's kangaroo rats have a large home range, widely scattered food caches, and a comparatively large hippocampus that makes up an average of $6.2 \%$ of total brain volume (Jacobs and Spencer, 1994). In contrast, 
bannertail kangaroo rats have a much smaller range, a central food hoard, and a comparatively small hippocampus (5.2\%).

There are also prominent structural differences within species. A series of studies in mice has confirmed the existence of heritable differences in the development of the hippocampus (Symons et al., 1988; Lipp et al., 1989) and has shown a good correspondence between hippocampal structural variation and learning ability among different strains, particularly spatial and contextual learning ability (Crusio et al., 1986; Lipp et al., 1989). We find that the hippocampus of $\mathrm{C} 57 \mathrm{BL} / 6 \mathrm{~J}$ is $\sim 5 \mathrm{mg}(20 \%)$ heavier than that of DBA/2J. At the level of single gene loci, the hippocampus of F2 progeny that have inherited both Hipp1 alleles from C57BL/6J are $1.3 \mathrm{mg}$ heavier than those of progeny that have inherited alleles from DBA/2J.

Upchurch and Wehner (1989) examined the inheritance of spatial learning and found that C57BL/6 mice are significantly better at spatial learning than DBA/2 mice. Several studies have also shown that the mossy fiber projection to CA3 is more extensive in C57BL/6 than in DBA/2J mice (Crusio et al., 1989; Schopke et al., 1991; Lassalle et al., 1999). We now add a $20 \%$ difference in granule cell number-the source of the mossy fiber projection - to this list of differences between the parental stains. The involvement of the projection from dentate gyrus to CA3 in learning and memory has been demonstrated in a variety of tasks (Schwegler and Lipp, 1983, Roullet and Lassalle, 1990; Bertholet and Crusio, 1991; Flint et al., 1995). It is plausible that allelic differences at Hipp1a and Hipp5a are functionally related to hippocampal-dependent behavioral differences that rely on the mossy fiber projection (Wehner et al., 1997; Lassalle et al., 1999).

In recent quantitative genetic studies of contextual conditioning, a learned behavior that depends on the hippocampus, a set of behavioral QTLs have been identified using precisely the same crosses-BXD and B6D2F2 - that we have used (Owen et al., 1997; Wehner et al., 1997). One of the most significant and well replicated QTLs identified in these studies is located on Chr 1 at $80 \pm 10$ cM (Flint et al., 1995; Caldarone et al., 1997; Owen et al., 1997; Wehner et al., 1997). The chance that the position of our strongest morphometric QTL, Hipp1, would match that of the single best behavioral QTL is small - this common $20 \mathrm{cM}$ interval makes up $<2 \%$ of the mouse genome. The $D$ allele at the learning locus on distal Chr 1 is strongly dominant and is associated with greater responsivity to a fearful context. In contrast, alleles at Hippla behave in an almost perfectly additive manner, and the $D$ allele in this case is associated with a smaller hippocampus. These differences argue either that Hippla and the contextual learning QTL are different loci or effects of alleles on anatomical and behavioral traits are not linearly related.

\section{Specificity of QTL action}

What assurance do we have that the QTLs we have mapped have specific effects on hippocampus and not widespread effects on many parts of the CNS? As a first line of defense we mapped hippocampal residuals - the signal that remains after controlling for major factors, particularly brain weight, age, and sex. As a second line of defense we have directly mapped QTLs that modulate brain weight and compared these QTLs with those that modulate hippocampal weight. We have previously mapped brain weight QTLs to Chrs 6, 7, 11, and 14 (Strom, 1999; Williams, 2000), but not to Chr 1 or Chr 5. However, an ongoing analysis of the F2 intercross used in the present study indicates that there is a brain weight QTL on distal Chr 1. This finding tempers our conclusion regarding the specificity of Hippla. Genetic and mo- lecular pathways will often have variable effects on different CNS regions (graded pleiotropy). For example, a QTL such as Hippla may have intense (but not exclusive) effects on hippocampus and modest effects on neocortex. This leads to a third line of defense: mapping QTLs that control other parts of the CNS in the same crosses. Hippla and Hipp5a do not correspond to any of the olfactory bulb or cerebellar QTLs we have mapped in BXD and the F2 crosses (Airey et al., 2001; Williams et al., 2001). Hipp1a and a cerebellar QTL, Cbs1a, both map near to each other on Chr 1 but B6 and D2 alleles at these QTLs have opposite effect polarities arguing against a common gene.

Regional volumetric and stereological analyses of the hippocampus indicate that Hippla and Hipp5a influence multiple parts of the hippocampus. The correlation between genotypes and phenotypes is significant for all the hippocampal traits, including total hippocampus weight, volume of the hippocampus proper, volumes of the dentate gyrus and the granule and pyramidal cell layers, and granule cell population. Even an axonprojection specific phenotype - the area of the mossy fiber projection to CA3 - significantly correlates to the Hippla locus (Lassalle et al., 1999). Both Hipp QTLs seem to affect adult hippocampus size selectively but have shared effects on most parts of the hippocampus.

\section{Candidate genes for Hipp1a and Hipp5a}

Hippla maps in the same region as the retinoid $\times$ receptor gamma $(\mathrm{RXR} \gamma)$ gene $(88 \mathrm{cM})$ on distal chromosome 1. During brain development, $\mathrm{RXR} \gamma$ and retinoid-binding proteins are expressed in CA1-CA3 and the hilus (Zetterstrom et al., 1999). There is evidence that allelic variants at this gene modulate hippocampal development. $\mathrm{RXR} \gamma$ is expressed in the adult murine hippocampus (Zetterstrom et al., 1999) and in $\mathrm{RXR} \gamma$ mutant mice, maze learning performance is compromised (Chiang et al., 1998), a finding that suggests that $\operatorname{RXR} \gamma$ is at least partly involved in hippocampal spatial learning and memory. It will be interesting to determine if this knock-out has an effect on hippocampal weight, volume of hippocampal regions, or on neuron number.

Gene expression profiling of the mouse hippocampus has also identified at least one polymorphic candidate gene near Hippla. Sandberg et al. (2000) compared mRNA expression levels of 13,000 genes in the hippocampus of C57BL/6Tac and 129S6/ SvEvTac. Their work highlighted an inward rectifying potassium channel gene (Kcnj9 or Girk3) that maps to distal Chr 1 (94 cM) and that is expressed at much lower levels in C57BL/6 than in 129S6. Kcnj9 is probably too distal to be a prime candidate for Hipp1a, but this example illustrates the power of QTL analysis when combined with microarray analysis.

Both BXD and F2 data sets indicate that Hipp $5 a$ maps between 15 and $40 \mathrm{cM}$ on Chr 5. This region contains two candidates$F g f r 3$ at $20 \mathrm{cM}$ and a cluster of GABA receptor genes at $40 \mathrm{cM}$. These candidate genes are expressed in the hippocampus during development and at maturity (Mohler et al., 1990; Asai et al., 1993; Peters et al., 1993; Gaiarsa et al., 1995). Fibroblast growth factordependent mechanisms influence a wide variety of CNS traits, including the survival, growth, and differentiation of hippocampal neurons (Walicke et al., 1986; Sasaki et al., 1992). GABA receptors are potential candidates because GABA is now known to have a trophic role in morphological development of hippocampal neurons (Barbin et al., 1993). With such a roughly defined QTL interval there are of course numerous other genes, many presumably still unknown that may influence hippocampal development. 


\section{Hippocampal size and sex differences}

Hippocampal size is a parameter with interesting functional correlates. Polygamous male voles traverse large home ranges in search of mates (Jacobs et al., 1990) and have large hippocampi. Polygamous kangaroo rats also exhibit a sex difference in home range size (Jacobs et al., 1994). Hippocampi of males are typically $10-15 \%$ larger than those of females. In these polygamous species, an increase in the size of the hippocampus is associated with superior spatial ability (Jacobs et al., 1990; Sherry et al., 1992). We found a smaller sex difference in laboratory mice that conforms to the pattern seen in wild rodent species-the hippocampus of males is $\sim 0.5 \mathrm{mg}$ heavier. However, this difference may be highly dependent on strain background. As much as a $15 \%$ difference in granule cell number was discovered between males and females of strain LG/J, whereas no significant sex difference was discovered in C58/J mice (Wimer and Wimer, 1985, 1989).

\section{Age-related changes in hippocampal weight and adult hippocampal neurogenesis}

Neurogenesis occurs in the dentate gyrus of the hippocampus throughout the life of a rodent (Kaplan et al., 1984; Kuhn et al., 1996). Kempermann et al. (1997b) reported that 3-month-old mice produce at least one new neuron per 2000 granule cells per day. Assuming complete additivity rather than turnover, this is equivalent to a $10 \%$ gain over a $200 \mathrm{~d}$ period. In mice, total granule cell number increases into midlife and then reaches a stable plateau (Kempermann et al., 1998). We have discovered a $10 \%$ gain in hippocampal weight over a $200 \mathrm{~d}$ period in adult mice. This correspondence is probably fortuitous, particularly so since the dentate gyrus - the only region with notable adult cell production-makes up only $\sim 20 \%$ of hippocampal weight.

Kempermann et al. (1997b) have shown that the production of new neurons in adults differs significantly among strains of mice, including those we have used in this study. Hippla and Hipp5a are therefore both QTLs that may influence neurogenesis. It is now feasible to test whether allelic variants at these QTLs modulate levels or kinetics of neurogenesis in the adult mouse. The analysis would rely on identifying 10-20 mice homozygous for either $B$ or $D$ alleles at the Hippla and Hipp5a intervals and phenotyping these genetically defined animals as adults. Just as is true of Mendelian mutations, an analysis of the functional role of allelic variants at QTLs can precede cloning. In fact, functional and developmental studies of QTLs (Strom and Williams, 1998) can greatly aid in narrowing the set of candidate genes that subsequently need to be analyzed in detail.

\section{REFERENCES}

Abusaad I, MacKay D, Zhao J, Stanford P, Collier DA, Everall IP (1999) Stereological estimation of the total number of neurons in the murine hippocampus using the optical disector. J Comp Neurol 408:560-566.

Airey DC, Lu L, Williams RW (2001) Genetic control of the mouse cerebellum: identification of quantitative trait loci modulating size and architecture. J Neurosci, in press.

Altman J, Das GD (1965) Autoradiographic and histological evidence of postnatal hippocampal neurogenesis in rats. J Comp Neurol 124:319-335.

Asai T, Wanaka A, Kato H, Masana Y, Seo M, Tohyama M (1993) Differential expression of two members of FGF receptor gene family, FGFR-1 and FGFR-2 mRNA, in the adult rat central nervous system. Brain Res Mol Brain Res 17:174-178.

Barber RP, Vaughn JE, Wimer RE, Wimer CC (1974) Geneticallyassociated variations in the distribution of dentate granule cell synapses upon the pyramidal cell dendrites in mouse hippocampus. J Comp Neurol 156:417-434.

Barbin G, Pollard H, Gaiarsa JL, Benari Y (1993) Involvement of $\mathrm{GABA}_{\mathrm{A}}$ Receptors in the outgrowth of cultured hippocampal neurons. Neurosci Lett 152:150-154.

Bayer SA (1982) Changes in the total number of dentate granule cells in juvenile and adult rats: a correlated volumetric and $3 \mathrm{H}$-thymidine autoradiographic study. Exp Brain Res 46:315-323.

Belknap JK, Hitzemann R, Crabbe JC, Phillips TJ, Buck KJ, Williams RW (2001) QTL analysis and genome-wide mutagenesis in mice: complementary genetic approaches to the dissection of complex traits. Behav Genet, in press.

Bertholet JY, Crusio WE (1991) Spatial and non-spatial spontaneous alternation and hippocampus mossy fiber distribution in nine inbred mouse strains. Behav Brain Res 43:197-202.

Bishop KM, Wahlsten D (1999) Sex and species differences in mouse and rat forebrain commissures depend on the method of adjusting for brain size. Brain Res 815:358-366.

Caldarone B, Saavedra C, Tartaglia K, Wehner JM, Dudek BC, Flaherty L (1997) Quantitative trait loci analysis affecting contextual conditioning in mice. Nat Genet 17:335-337.

Cameron HA, Woolley CS, McEwen BS, Gould (1993) Differentiation of newly born neurons and glia in the dentate gyrus of the adult rat. Neuroscience 56:337-344.

Chiang MY, Misner D, Kempermann G, Schikorski T, Giguere V, Sucov HM, Gage FH, Stevens CF, Evans RM (1998) An essential role for retinoid receptors RAR $\beta$ and RXR $\gamma$ in long-term potentiation and depression. Neuron 21:1353-1361.

Churchill GA, Doerge RW (1994) Empirical threshold values for quantitative trait mapping. Genetics 138:963-971.

Crusio WE, Genthner-Grimm G, Schwegler H (1986) A quantitativegenetic analysis of hippocampal variation in the mouse. J Neurogenet 3:203-214.

Crusio WE, Schwegler H, van Abeelen JHF (1989) Behavioral responses of novelty and structural variation of hippocampus in mice: II. Multivariate genetic analysis. Behav Brain Res 32:81-88.

Csernansky JG, Joshi S, Wang L, Haller JW, Gado M, Miller P, Grenander U, Miller MI (1998) Hippocampal morphometry in schizophrenia by high dimensional brain mapping. Proc Natl Acad Sci USA 95:11406-11411.

Darvasi A (1998) Experimental strategies for the genetic dissection of complex traits in animals. Nat Genet 18:19-24.

De Bellis MD, Clark DB, Beers SR, Soloff PH, Boring AM, Hall J, Kersh A, Keshavan MS (2000) Hippocampal volume in adolescent-onset alcohol disorders. Am J Psych 157:737-744.

Dietrich WF, Katz H, Lincoln SE (1992) A genetic map of the mouse suitable for typing in intraspecific crosses. Genetics 131:423-447.

Don RH, Cox PT, Wainwright BJ, Baker K, Mattick JS (1991) "Touchdown" PCR to circumvent spurious priming during gene amplification. Nucleic Acids Res 19:4008.

Flint J, Corley R, DeFries JC, Fulker DW, Gray JA, Miller S, Collins AC (1995) A simple genetic basis for a complex psychological trait in laboratory mice. Science 269:1432-1435.

Gaiarsa JL, McLean H, Congar P, Leinekugel X, Khazipov R, Tseeb V, Ben-Ari Y (1995) Postnatal maturation of gamma-aminobutyric acid $\mathrm{A}$ and $\mathrm{B}$-mediated inhibition in the CA3 hippocampal region of the rat. J Neurobiol 26:339-349.

Gould E, Cameron HA, McEwen BS (1994) Blockade of NMDA receptors increases cell death and birth in the developing rat dentate gyrus. J Comp Neurol 22:551-565.

Haley CS, Knott SA (1992) A simple regression method for mapping quantitative trait loci in line crosses using flanking markers. Heredity 69:315-324.

Hatton WJ, von Bartheld CS (1999) Analysis of cell death in the trochlear nucleus of chick embryos: calibration of the optical disector counting technique reveals systematic bias. J Comp Neurol 409:169-186.

Hegmann JP, Possidente B (1981) Estimating genetic correlations from inbred strains. Behav Genet 11:103-114.

Howard CV, Reed MG (1998) Unbiased stereology. Three-dimensional measurement in microscopy. New York: Springer.

Jacobs LF, Spencer WD (1994) Natural space-use patterns and hippocampal size in kangaroo rats. Brain Behav Evol 44:125-132.

Jacobs LF, Gaulin SJC, Sherry DF, Hoffman GE (1990) Evolution of spatial cognition: sex-specific patterns of spatial behavior predict hippocampal size. Proc Natl Acad Sci USA 87:6349-6352.

Kaplan MS, Bell DH (1984) Mitotic neuroblasts in the 9-day-old and 11-month-old rodent hippocampus. J Neurosci 4:1429-1441.

Kempermann G, Kuhn HG, Gage FH (1997a) More hippocampal neurons in adult mice living in an enriched environment. Nature 386:493-495

Kempermann G, Kuhn HG, Gage FH (1997b) Genetic influence on neurogenesis in the dentate gyrus of adult mice. Proc Natl Acad Sci USA 94:10409-10414.

Kempermann G, Kuhn HG, Gage FH (1998) Experience-induced neurogenesis in the senescent dentate gyrus. J Neurosci 18:3206-3212.

Kuhn HG, Dickinson-Anson H, Gage FH (1996) Neurogenesis in the dentate gyrus of the adult rat: age-related decrease of neuronal progenitor proliferation. J Neurosci 16:2027-2033.

Kuhn HG, Winkler J, Kempermann G, Thal LJ, Gage FH (1997) Epidermal growth factor and fibroblast growth factor-2 have different 
effects on neural progenitors in the adult rat brain. $J$ Neurosci 17:5820-5829.

Laird PW, Zijderveld A, Linders K, Rudnicki M, Jaenisch R, Berns A (1991) Simplified mammalian DNA isolation procedure. Nucleic Acids Res 19:4293.

Lander ES, Schork NJ (1994) Genetic dissection of complex traits. Science 265:2037-2048.

Lassalle JM, Halley H, Milhaud JM, Roullet P (1999) Genetic architecture of the hippocampus mossy fiber subfields in the BXD RI mouse strain series: a preliminary QTL analysis. Behav Genet 29:273-282.

Lipp HP, Wolfer DP (1998) Genetically modified mice and cognition. Curr Oppin Neurobiol 8:272-280.

Lipp HP, Schwegler H, Crusio WE, Wolfer DP, Leisinger-Trigona MC, Heimrich B, Driscoll P (1989) Using genetically-defined rodent strains for the identification of hippocampal traits relevant for two-way avoidance behavior: a non-invasive approach. Experientia 45:845-859.

Love JM, Knight AM, McAleer MA, Todd JA (1990) Towards construction of a high resolution map of the mouse genome using PCRanalyzed microsatellites. Nucleic Acids Res 18:4123-4130.

Lynch M, Walsh B (1998) Genetics and analysis of quantitative traits. Sunderland, MA: Sinauer.

Manly K (1993) A Macintosh program for storage and analysis of experimental genetic mapping data. Mamm Genome 4:303-313.

Manly KF, Olson JM (1999) Overview of QTL mapping software and introduction to Map Manager QT. Mamm Genome 10:327-334.

Mohler H, Malherbe P, Draguhn A, Richards JG (1990) GABA - receptors: structural requirements and sites of gene expression in mammalian brain. Neurochem Res 15:199-207.

Owen EH, Logue SF, Rasmussen DL, Wehner JM (1997) Assessment of learning by the Morris water task and fear conditioning in inbred mouse strains and F1 hybrids: implications of genetic background for single gene mutations and quantitative trait loci analyses. Neuroscience 80:1087-1099.

Palmer TD, Takahashi J, Gage FH (1997) The adult rat hippocampus contains primordial neural stem cells. Mol Cell Neurosci 8:389-404.

Peters K, Ornitz D, Werner S, Williams L (1993) Unique expression pattern of the FGF receptor 3 gene during mouse organogenesis. Dev Biol 155:423-430.

Rikke BA, Johnson TE (1998) Towards the cloning of genes underlying murine QTLs. Mamm Genome 9:963-968.

Rosen GD, Williams RW (2001) Complex trait analysis of the mouse striatum: independent QTLs modulate volume and neuron number. BMC Neurosci, in press.

Roullet P, Lassalle JM (1990) Genetic variation, hippocampal mossy fibers distribution, novelty reactions and spatial representation in mice. Behav Brain Res 41:61-69.

Routman E, Cheverud J (1994) A rapid method of scoring simple sequence repeat polymorphisms with agarose gel electrophoresis. Mamm Genome 5:187-188.

Sandberg R, Yasuda R, Pankratz DG, Carter TA, Del Rio JO, Wodicka L, Mayford M, Lockhart DJ, Barlow C (2000) Regional and strainspecific gene expression mapping in the adult mouse brain. Proc Natl Acad Sci USA 97:11039-11043.

Sasaki K, Oomiya Y, Suzuki K, Hanal K, Yagi H (1992) Acidic fibroblast growth factor prevents death of hippocampal CA1 pyramidal cells following ischemia. Neurochem Int 21:397-402.

Schopke R, Wolfer DP, Lipp HP, Leisinger-Trigona MC (1991) Swimming navigation and structural variations of the infrapyramidal mossy fibers in the hippocampus of the mouse. Hippocampus 1:315-328.

Schwegler H, Lipp HP (1983) Hereditary covariations of neuronal circuitry and behavior: correlations between the proportions of hippocampal synaptic fields in the regio inferior and two-way avoidance in mice and rats. Behav Brain Res 7:1-38.

Sherry DF, Jacobs LF, Gaulin SJ (1992) Spatial memory and adaptive specialization of the hippocampus. Trends Neurosci 15:298-303.

Sokal RR, Rohlf FJ (1995) Biometry: the principles and practice of statistics in biological research, Ed 3. New York: Freeman.

Stanfield BB, Trice JE (1988) Evidence that granule cells generated in the dentate gyrus of adult rats extend axonal projections. Exp Brain Res 72:399-406.
Strom RC (1999) Genetic analysis of variation in neuron number. PhD Dissertation, University of Tennessee, Memphis. www.nervenet.org/ papers/Strom99/Thesis.html.

Strom RC, Williams RW (1998) Cell production and cell death in the generation of variation in neuron number. J Neurosci 18:9948-9953.

Symons JP, Davis RE, Marriott JG (1988) Water-maze learning and effects of cholinergic drugs in mouse strains with high and low hippocampal pyramidal cell counts. Life Sciences 42:375-383.

Tanksley SD (1993) Mapping polygenes. Annu Rev Genet 27:205-233.

Taylor BA (1989) Recombinant inbred strains. In: Genetic variants and strains of the laboratory mouse, Ed 2 (Lyon ML, Searle AG, eds), pp 773-796. Oxford: Oxford UP.

Taylor BA, Wnek C, Kotlus BS, Roemer N, MacTaggart T, Phillips SJ (1999) Genotyping new BXD recombinant inbred mouse strains and comparison of BXD and consensus maps. Mamm Genome 10:335-348.

Upchurch M, Wehner JM (1989) Inheritance of spatial learning ability in inbred mice: a classical genetic analysis. Behav Neurosci $103: 1251-1258$

von Bartheld CS (1999) Systematic bias in an "unbiased" neuronal counting technique. Anat Rec 257:119-120.

Walicke P, Cowan WM, Ueno N, Baird A, Guillemin R (1986) Fibroblast growth factor promotes survival of dissociated hippocampal neurons and enhances neurite extension. Proc Natl Acad Sci USA 83:3012-3016.

Wehner JM, Radcliffe RA, Rosmann ST, Christensen SC, Rasmussen DL, Fulker DW, Wiles M (1997) Quantitative trait locus analysis of contextual fear conditioning in mice. Nat Genet 17:331-334.

Williams RW (1998) Neuroscience meets quantitative genetics: using morphometric data to map genes that modulate CNS architecture. In: Short course in quantitative neuroanatomy, pp 66-78. Washington, DC: Society for Neuroscience. www.nervenet.org/papers/ShortCourse98.html.

Williams RW (2000) Mapping genes that modulate mouse brain development: a quantitative genetic approach. In: Mouse brain development. (Goffinet A, Rakic P, eds), pp 21-49. Berlin: Springer.

Williams RW, Rakic P (1988) Three-dimensional counting: an accurate and direct method to estimate numbers of cells in sectioned material. J Comp Neurol 278:344-352 and 281:355.

Williams RW, Strom RC, Goldowitz D (1998) Natural variation in neuron number in mice is linked to a major quantitative trait locus on Chr 11. J Neurosci 18:138-146.

Williams RW, Airey DC, Kulkarni A, Zhou G, Lu L (2001a) Genetic dissection of the olfactory bulb of mice: QTLs on chromosomes 4, 6, 11, and 17 modulate bulb size. Behav Genet, in press.

Wimer CC, Wimer RE (1971) Some behavioral differences associated with relative size of hippocampus in the mouse. J Comp Physiol Psychol 76:57-65.

Wimer RE, Wimer CC (1982) A biometrical-genetic analysis of granule cell number in the area dentata of house mice. Dev Brain Res 2:129-140.

Wimer CC, Wimer RE (1989) On the sources of strain and sex differences in granule cell number in the dentate area of house mice. Dev Brain Res 48:167-176.

Wimer CC, Wimer RE, Wimer JS (1983) An association between granule cell density in the dentate gyrus and two-way avoidance conditioning in the house mouse. Behav Neurosci 97:844-855.

Wimer RE, Wimer C (1985) Three sex dimorphisms in the granule cell layer of the hippocampus in house mice. Brain Res 328:105-109.

Wimer RE, Wimer CC, Vaughn JE, Barber RP, Balvanz BA, Chernow CR (1976) The genetic organization of neuron number in Ammon's horns of house mice. Brain Res 118:219-243.

Wimer RE, Wimer CC, Vaughn JE, Barber RP, Balvanz BA, Chernow CR (1978) The genetic organization of neuron number in the granule cell layer of the area dentata in house mice. Brain Res 157:105-122.

Zetterstrom RH, Lindqvist E, Urquiza AM, Tomac A, Eriksson U, Perlmann T, Olson L (1999) Role of retinoids in the CNS: differential expression of retinoid binding proteins and receptors and evidence for presence of retinoic acid. Eur J Neurosci 11:407-416.

Zhou GM, Williams RW (1999) Eye1 and Eye2: gene loci that modulate eye size, lens weight, and retinal area in mouse. Invest Ophthalmol Vis Sci 40:817-825. 